\title{
THE EFFECT OF ORGANIZATION'S STRUCTURE AND TASK CHARACTERISTICS ON TEAM EFFECTIVENESS IN TUBERCULOSIS PREVENTION PROGRAM
}

\author{
Pengaruh Struktur Organisasi dan Karakteristik Tugas terhadap Efektivitas Tim pada \\ Program Pencegahan Tuberculosis
}

"Sinta D. Lestyoningrum¹, Thinni N. Rochmah', Dewi R. Suminar², Ulfia Hazna Safira1

${ }^{1}$ Department of Health Administration and Policy, Faculty of Public Health, Airlangga University, Indonesia

${ }^{2}$ Department of Educational and Developmental Psychology, Faculty of Psychology, Airlangga University, Indonesia

*Correspondence: sinta.dewi.lestyoningrum-2017@fkm.unair.ac.id

\begin{abstract}
Background: A team is a vital element for an organization. An organization should put efforts to improve team performance even though they might face some obstacles. Organization's structure and task characteristics resulted in different team effectiveness of primary healthcare centers in preventing tuberculosis (TB) cases in Surabaya.

Aims: This study aimed to identify the effect of organization's structure and task characteristics on team effectiveness of primary healthcare centers in TB prevention program in Surabaya.

Methods: The research was a quantitative study using a cross-sectional approach. Questionnaires were disseminated to 43 respondents as the samples selected with a proportional stratified random sampling technique based on the success rate. The respondents consisted of doctors, nurses, and health analysts who were directly involved in the Tuberculosis prevention program. This study used a linear multivariable regression test to confirm the most significant model for the independent variable.

Results: The span of control and centralization had a significant effect on task characteristics (sig 0.00; sig 0.017). The dimensions of task characteristics that had a significant effect on team effectiveness were task variety, task identity, and task significance.

Conclusion: There was a significant effect of span of control and centralization on task characteristics. The primary healthcare centers should provide access to technology to upgrade the span of control and centralization and their understanding of task characteristics.
\end{abstract}

Keywords: health services, organization's structure, task characteristics, team effectiveness, tuberculosis.

\section{ABSTRAK}

Latar Belakang: Tim merupakan salah satu elemen penting dalam sebuah organisasi. Sebuah organisasi perlu berupaya dalam meningkatkan kinerja tim meskipun menghadapi beberapa hambatan. Struktur organisasi dan karakteristik tugas menunjukkan efektifitas tim Puskesmas yang berbeda dalam penanggulangan TB di Surabaya.

Tujuan: Penelitian ini mengidentifikasi pengaruh antara struktur organisasi dan karakteristik tugas terhadap efektifitas tim penanggulangan TB di Puskesmas Kota Surabaya.

Metode: Penelitian ini adalah penelitian kuantitatif dengan menggunakan pendekatan potong lintang. Kuisoner disebarkan kepada 43 sampel diambil dengan teknik proportional stratified random sampling berdasarkan capaian success rate. Responden terdiri dari dokter, perawat dan analis kesehatan yang terlibat langsung dengan program TB. Penelitian ini menggunakan tes multivariable regresi linier untuk mengkonfirmasi model yang paling signifikan terhadap variabel independen.

Hasil: Span of control dan centralization berpengaruh signifikan terhadap karakteristik tugas (sig 0,00; sig 0,017). Dimensi karakteristik tugas yang berpengaruh signifikan terhadap efektifitas tim adalah jenis tugas, identitas tugas, dan signifikansi tugas.

Kesimpulan: Terdapat pengaruh signifikan antara span of control dan centralization dengan karakteristik tugas. 
Puskesmas perlu menggunakan teknologi untuk memperbaharui span of control dan centralisation dan meningkatkan pemahaman setiap anggota tim terhadap jenis tugas, identitas tugas, dan signifikansi tugas.

Kata kunci: pelayanan kesehatan, struktur organisasi, karakteristik tugas, efektifitas tim, tuberculosis.

\section{INTRODUCTION}

Tuberculosis is an infectious disease caused by Mycobacterium tuberculosis agent (Indonesian Ministry of Health, 2016). Webber (2009) identified that the main bacteria causing tuberculosis is Mycobacterium tuberculosis, but Mycobacterium bovis and Mycobacterium africanum are also two other affecting bacteria. Tuberculosis (TB) is caused by gram-positive aerobe bacteria and fatty acids bacteria which attack the lungs and other organs. Based on the Regulation of the Indonesian Ministry of Health No. 67 of 2016 about tuberculosis prevention, TB can be contagious as a patient with TB coughs up sputum, which contains bacteria. A patient with TB who sneezes or coughs can release droplets of contagious sputum through the air. Infection may occur if someone inhales air with droplets of contagious sputum as many as 3,000 . It means that the number of bacteria inhaled are around $0-3,500$ Mycobacterium tuberculosis. Meanwhile, if a patient with TB sneezes, droplets of sputum can infect others with 4,500-1,000,000 Mycobacterium tuberculosis.

It was predicted that 10 million TB cases or 133 cases per 100,000 populations with 558,000 multidrugresistant tuberculosis (MDR-TB) cases would occur worldwide in 2017 (Indonesian Ministry of Health, 2016). There were about 1.3 million mortalities due to TB and 300,000 mortalities due to TB with HIV. In 2017, deaths due to (TB) decreased by nearly $3 \%$ every year. The decrease in mortality rates from 2000 to 2017 was at 42\% (World Health Organization, 2017). East Java was ranked in the second among other provinces in Indonesia for 26,152 newly discovered positive acid-fast bacilli or Case Notification Rate (CNR) of 67 per 100,000 population (East Java Provincial Health Office, 2017). Surabaya had the highest number of tuberculosis cases in East Java with the success rate of less than $90 \%$.

In Indonesia, a TB prevention program is implemented by primary healthcare centers as the first-level primary healthcare facilities. They chose a team that consists of doctors, nurses, and health analysts. The program includes several vital activities, such as health promotion, case detection, recovery, as well as improvement in the quality of patients' life. Health promotion becomes an educational approach tp prevent and protect individuals and community from TB. TB case detection is a tracking on TB positive cases and recovery as curative services.

McShane and Glinow (2015) defined a team as a group of two people or more who interact and have the same goals as the organization's. McShane and Von also mentioned that all members should recognize their involvement as a part of the organization. Task is not organized individually, but all members should have common and clear goals and work together. A task is done by a group of individuals in a small system with a broader scale (Lukas, Mohr and Meterko, 2009). Nowaday's public organization management has changed to work from a hierarchical structure to team decentralization. Dividing a particular roles and responsibilities for team members will affect the organization's achievement and 
goals (Kramer, Thayer and Salas, 2013).

A new information system can help achieve the annual target and support the evaluation of TB prevention programs. Without information system, health workers are difficult to determine the right actions in TB prevention program. In spite of information system, cooperation among health workers supports the achievement of targets in TB prevention program.

An organization's structure contributes to building cooperation and teamwork among health workers. However, targets can be achieved not only with a good organization's structure, but also clear and precise task characteristics. Similar task characteristics can make a team perform outstandingly. This study initially found that organization's structure and similar task characteristics which primary healthcare centers of Surabaya assigned resulted in ineffective performance. They still had an unclear division of tasks, such as double tasks that made their team not perform effectively. Meanwhile, the task characteristics were different for each member due to the complexity of the tasks. The Health Profile by East Java Provincial Health Office (2017) and Indonesian Ministry of Health (2017) showed the average CDR (Case Detection Rate) achievement rate of TB prevention program in Surabaya was $60.17 \%$ with MSS (Minimum Service Standard) of $77 \%$ in $2015,74.88 \%$ with MMS of $85 \%$ in 2016 , and $83.53 \%$ with MMS of $90 \%$ in 2017.

Team effectiveness is the condition to achieve goals, meet needs and objectives of team members, and maintain their relationship. It can be assessed from outputs produced by the team in completing a task. McShane and Glinow (2018) mentioned three factors including organizational environment, team design and team process can influence team effectiveness. Organizational environment consists of appreciation, communication, organization's structure, organizational leadership, and physical space. Team design consists of task characteristics, team size and team composition. While, team process consists of team development, team norms, team cohesion and team trust. All of these indicators affect team effectiveness. If team effectiveness is not achieved, the team will have difficulty in achieving their target and the emergence of dissatisfaction among team members (Diagram 1).

Even though similar task characteristics and organization's structure were found, the team members did not have the same perception. Therefore, this study identified the effect of organization's structure and task characteristics on team effectiveness for TB prevention program in all primary healthcare centers of Surabaya.

\section{METHOD}

This study was observational research using a cross-sectional design. The population in this study were all tuberculosis prevention groups in primary healthcare centers. The sample was obtained using a proportional stratified random sampling based on the target success rate of the primary healthcare centers in Surabaya. Forty-three groups were obtained from sample calculations using a reference to achieving the 2018 target success rate that showed the final results of TB control and the quality of TB treatment given. With the success rate achieved at >90.01\%, 29 TB control teams were involved. For primary healthcare centers with the unachieved success rate at $<90.00 \%, 14$ prevention teams were still included. Thus, there were 43 groups participating in this study. This empirical study distributed questionnaires which validity and reliability have been tested with the Pearson test.

The researchers and enumerators disseminated questionnaires to 43 groups of health workers assigned to handle the TB prevention program in all primary 
healthcare centers of Surabaya. This study obtained an informed consent during the data collection, which was done voluntary and confidentiality. After getting permission from the primary healthcare centers, the researchers and enumerators conducted forum group discussion with health workers to TB prevention program. The data were collected twice from doctors, nurses, and health analysts who worked closely with patients in needs of TB treatment. In the first meeting, questionnaires about organization's structure and task characteristics were disseminated. Then, the researchers gave questionnaires about team effectiveness in the second meeting. Both questionnaires were spread to 345 health workers, but only 318 health workers completely answered. For organization's structure variable, members' perceptions of the team structure were assessed from three indicators, such as span of control, centralization and formalization. While, a task characteristic variable was formed by following work design questionnaire which consisted of autonomous tasks, task variety, task identity, task significance, task feedback and task interdependence. The questionnaires had four scales; strongly disagree, disagree, agree, and strongly agree. The team score was calculated from the average scores of all members (Ehrhardt et al., 2018). The average score of each team was obtained from a linear multivariable regression test. If the P-value was less than $\alpha$-value (0.05), it could give significance. A backward model was applied in the test to find out the most significant model for the dependent variable. The multivariable analysis could seek for the prevalence risk or prevalence ratio, which showed the significance of tested variables. Thus, it could help determine the effect on each variable.

Organization's structure as the independent variable was measured from
3 dimensions; span of control, centralization, and formalization. For example, the questionnaire regarding span of control stated "To me, one or more health workers were assigned to TB prevention program to give a direct report to the managers of primary healthcare centers or to Surabaya District Health Office." The centralisation dimension questionnaire stated "I think the health workers assigned to prevent TB have the authority to make an official decision on TB prevention program." Regarding formalization dimension, the questionnaire stated "I guess, the health workers assigned have SOPs in the implementation of TB prevention program." The final assessment of organization's structure was scaled from very ineffective, ineffective, effective, and very effective. Task characteristics variable consisted of some dimensions; task autonomy, task variety, task identity, task significance, task feedback, and task interdependence. Task characteristics questionnaire was modified using the work design questionnaire of Morgeson, Frederick and Humphrey (2006) with 20 questions. This variable was categorized into very low, low, high, and very high.

On the other hand, team effectiveness as the dependent variable was measured from satisfaction with member's needs and team maintenance as initiated by McShane and Glinow (2015). Team effectiveness questionnaire consisted of 11 questions for asking the success rate in each indicator. Team effectiveness was categorized into highly ineffective, ineffective, effective, and very effective. The overall team score was obtained from the average score of all members. Data were then descriptively analyzed to calculate the mean of each variable's dimension with the Pareto principle. This principle explained that $80 \%$ effects would occur because of $20 \%$ causes. The mean of variable and its 
dimension was considered problematic if the accumulation of score from the lowest two categories was less than $20 \%$. The cutting point of mean was considered unacceptable if $80 \%$ effects multiplied with a maximum score of 4 for each answer was 3.20. This study has obtained an ethical clearance approved by the Health Research Ethics Committee, Faculty of Nursing, Universitas Airlangga (No.: 1316KEPK).

\section{ORGANIZATION LEVEL}

Organization's Characteristics

1. Vision rules and goal management

2. Division

3. Training and awards

1. Awarding

Organization and Team Environment

2. Communication

3. Organizational structure

4. Organizational leadership

5. Physical space

\section{INDIVIDUAL LEVEL}

1. Ability and skills

2. Experience

3. Age

4. race

5. Gender

6. Individual psychology

a. Perception

b. Behavior

c. Personality

d. Learning

e. Motivation

\section{TEAM DESIGN}

1. Task characteristics

2. Team size

3. Team composition

\section{TEAM PROCESS}

1. Task characteristics

2. Team size

3. Team composition

Diagram 1. Theoretical Framework of Team Effectiveness

Source: Team Effectiveness Model (McShane and Glinow, 2018)

\section{RESULTS AND DISCUSSION}

This study aimed to analyze the effect of organization's structure and task characteristics on team effectiveness for TB prevention program. Diagram 2 illustrates how team effectiveness as the dependent variable was affected by organization's structure and task characteristics as the independent variables. From the analysis, this study found out the analysis results of each dimension of the independent variables in Table 1.

Table 1 showed most of the teams perceived that the organization's structure was effective. Whereas, $37.2 \%$ of the teams had a very effective formalization. The centralization dimension had a mean value of $<3.20$, meaning the teams perceived not having an authority to make an official decision on the program. While, the other dimensions, i.e., span of control and formalization, obtained the mean of $>3.20$. This indicates that the teams had already appointed one or more people to report directly to the managers of the primary healthcare centers. They also had SOPs in implementing the program. 


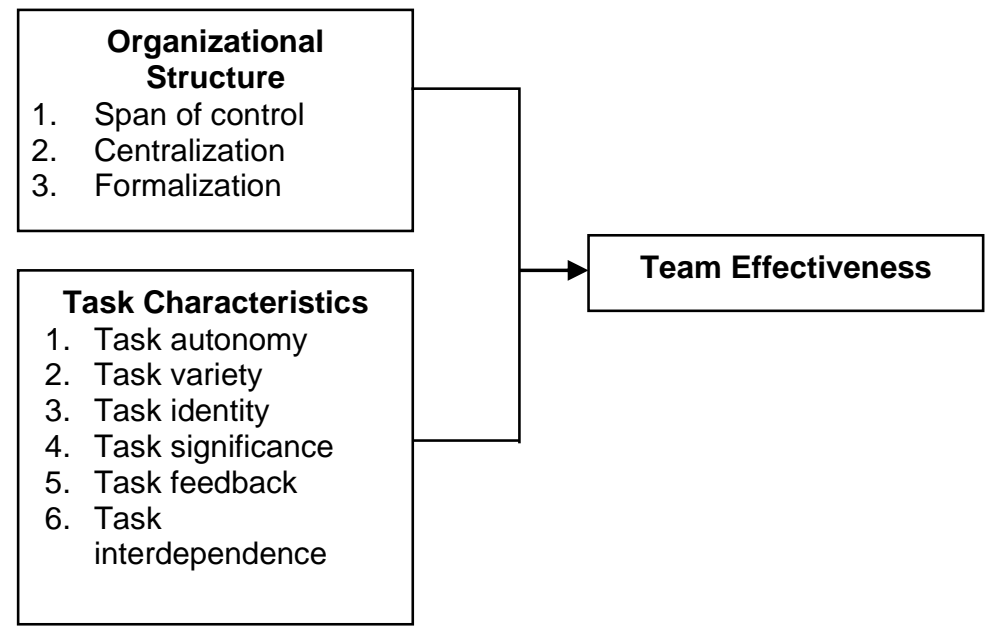

Diagram 2. Research Framework

Table 1. Perceptions of Conditions per Indicator of the Organizational Structure of TB Control Teams in Primary Health Cares in Surabaya City in 2019.

\begin{tabular}{|c|c|c|c|c|c|c|c|c|c|c|}
\hline \multirow{2}{*}{ Dimension } & \multicolumn{2}{|c|}{$\begin{array}{c}\text { Very } \\
\text { ineffective }\end{array}$} & \multicolumn{2}{|c|}{ Ineffective } & \multicolumn{2}{|c|}{ Effective } & \multicolumn{2}{|c|}{ Very Effective } & \multicolumn{2}{|c|}{ Total } \\
\hline & $\mathbf{n}$ & $\%$ & $\mathbf{n}$ & $\%$ & $\mathrm{n}$ & $\%$ & $\mathrm{n}$ & $\%$ & $\mathrm{n}$ & $\%$ \\
\hline \multicolumn{11}{|c|}{ Organization's structure } \\
\hline \multirow[t]{2}{*}{$\begin{array}{l}\text { Designating a } \\
\text { person to report } \\
\text { about TB cases }\end{array}$} & 0 & 0.0 & 0 & 0.0 & 31 & 72.1 & 12 & 27.9 & 43 & 100.00 \\
\hline & & & & & & & & & Mean & 3.28 \\
\hline \multicolumn{11}{|l|}{ Centralization } \\
\hline \multirow[t]{2}{*}{$\begin{array}{l}\text { Authority for } \\
\text { taking an official } \\
\text { decision }\end{array}$} & 0 & 0.0 & 0 & 0.0 & 37 & 86.0 & 6 & 14.0 & 43 & 100.00 \\
\hline & & & & & & & & & Mean & 3.14 \\
\hline \multirow[t]{2}{*}{$\begin{array}{l}\text { Formalization } \\
\text { SOPs in the } \\
\text { implementation } \\
\text { of TB prevention } \\
\text { program }\end{array}$} & 0 & 0.0 & 0 & 0.0 & 27 & 62.8 & 16 & 37.2 & 43 & 100.00 \\
\hline & & & & & & & & & Mean & 3.37 \\
\hline
\end{tabular}

Furthermore, $79.1 \%$ of the teams perceived that they had an effective organization's structure. The centralization dimension had the lowest mean of 3.14. It refers to the decision-making process which can be both authority hierarchy and participation. Decision-making on task division and activity implementation is centralized when the authority hierarchy is applied. Independent decision-making indicates low authority hierarchy (Hage, Jerald, and Aiken, 1967; Jones, 2013).
Whereas, a decision made by the organization leads to employee's participation (Hage and Aiken, 1967). The teams had low participation in decisionmaking since higher stakeholders, such as District Health Office, Provincial Health Office, or Ministry of Health took control over this process. According to Lambert, lii, and Lynne (2006), the centralisation dimension could affect employee satisfaction. For instance, employees with less contribution in decision-making and 
less authority will feel unsatisfied about their work. Even though the authority hierarchy and participation affect team satisfaction, these do not impact on organization's public services (Rhys et al., 2009).

Table 2 shows the mean of all the task characteristics dimensions was at $<3.20$ except for task significance which the mean was at 3.33. That the mean of task significance was $>3.20$ showed the teams' high task significance. However, the teams still had low task autonomy, task variation, task identity, task reciprocity, and task engagement which the mean was $<3.20$.

This study revealed most of each task characteristics were in a high scale. The Regulation of Indonesian Ministry of Health No.67 of 2016 about TB treatment states the means of team authority, task variety, task identity, task feedback, and task significance are commonly less than 3.20. The teams' perception of task characteristics was low since not all team members were involved in dividing tasks based on their competency. Task characteristics could evaluate a task model focused on task characteristics to sound more interesting and motivating for employees (Folami and Jacobs, 2005). Hackman, Richard, Oldham and Greg (1976) stated that task characteristics have five dimensions; task variety, task identity, task significance, task autonomy, and task feedback. Meanwhile, McShane and Glinow (2015) mentioned task interdependence despite those five dimensions.

The results showed $86.0 \%$ of the teams perceived they performed the program effectively. Indicated satisfaction with their needs and team maintenance hadof the means of less than 3.20 , this study found the team effectiveness was still low. Only $9.3 \%$ of the teams were satisfied with the fulfillment of their needs. It means the majority of primary healthcare centers formed a team by force. Since they had different facilities and targets, they could not ensure the fulfillment of their members' needs.

Table 2. Perceptions of Conditions per Task Characteristics Indicator of TB Control Teams in Primary Health Cares in Surabaya City in 2019.

\begin{tabular}{|c|c|c|c|c|c|c|c|c|c|c|}
\hline \multirow[t]{2}{*}{ Dimension } & \multicolumn{2}{|c|}{ Very Low } & \multicolumn{2}{|c|}{ Low } & \multicolumn{2}{|c|}{ High } & \multicolumn{2}{|c|}{ Very High } & \multicolumn{2}{|c|}{ Total } \\
\hline & $\mathbf{n}$ & $\%$ & $\mathbf{n}$ & $\%$ & $\mathbf{n}$ & $\%$ & $\mathbf{n}$ & $\%$ & $\mathbf{n}$ & $\%$ \\
\hline \multicolumn{11}{|l|}{ Task Characteristics } \\
\hline \multirow[t]{2}{*}{ Task Autonomy } & \multirow{2}{*}{0} & \multirow[t]{2}{*}{0.0} & \multirow[t]{2}{*}{0} & \multirow[t]{2}{*}{0.0} & \multirow[t]{2}{*}{40} & \multirow[t]{2}{*}{93.0} & \multirow[t]{2}{*}{3} & \multirow[t]{2}{*}{7.0} & 43 & 100.00 \\
\hline & & & & & & & & & Mean & 3.07 \\
\hline \multirow[t]{2}{*}{ Task Variety } & \multirow[t]{2}{*}{0} & \multirow[t]{2}{*}{0.0} & \multirow[t]{2}{*}{0} & \multirow[t]{2}{*}{0.0} & \multirow[t]{2}{*}{37} & \multirow[t]{2}{*}{86.0} & \multirow[t]{2}{*}{6} & \multirow[t]{2}{*}{14.0} & 43 & 100.00 \\
\hline & & & & & & & & & Mean & 3.14 \\
\hline \multirow[t]{2}{*}{ Task Identity } & \multirow[t]{2}{*}{0} & \multirow[t]{2}{*}{0.0} & \multirow[t]{2}{*}{0} & \multirow[t]{2}{*}{0.0} & \multirow[t]{2}{*}{40} & \multirow[t]{2}{*}{93.0} & \multirow[t]{2}{*}{3} & \multirow[t]{2}{*}{7.0} & 43 & 100.00 \\
\hline & & & & & & & & & Mean & 3.07 \\
\hline \multirow[t]{2}{*}{ Task Significance } & \multirow[t]{2}{*}{0} & 0.0 & 0 & 0.0 & 29 & 67.4 & 14 & 32.6 & 43 & 100.00 \\
\hline & & & & & & & & & Mean & 3.33 \\
\hline Task Feedback & 0 & 0.0 & 0 & 0.0 & 37 & 86.0 & 6 & 14.0 & 43 & 100.00 \\
\hline & & & & & & & & & Mean & 3.19 \\
\hline $\begin{array}{l}\text { Task } \\
\text { Interdependence }\end{array}$ & 0 & 0.0 & 0 & 0.0 & 39 & 90.7 & 4 & 9.3 & 43 & 100.00 \\
\hline & & & & & & & & & Mean & 3.14 \\
\hline
\end{tabular}


Table 3. The Effect of Organization's Structure on Task Characteristics.

\begin{tabular}{ccc}
\hline $\begin{array}{c}\text { Dimensions of Organization's } \\
\text { Structure }\end{array}$ & Sig. & $\begin{array}{c}\text { Standardized Coefficients } \\
\text { Beta }\end{array}$ \\
\hline Span of Control & & 0.538 \\
\hline Centralisation & $0.000^{\star *}$ & 0.315 \\
\hline Formalization & $0.017^{\star *}$ & 0.194 \\
\hline $\begin{array}{l}\text { Dependent Variable: Task Characteristics } \\
\left.{ }^{*}\right)=\text { significance }<0.05\end{array}$ & 0.128 & \\
\hline
\end{tabular}

Table 4. The Effect of Task Characteristics on Team Effectiveness in TB Prevention Program.

\begin{tabular}{lcc}
\hline $\begin{array}{c}\text { Dimensions of Organization's } \\
\text { Structure }\end{array}$ & Sig. & $\begin{array}{c}\text { Standardized Coefficients } \\
\text { Beta }\end{array}$ \\
\hline Task Autonomy & 0.459 & 0.067 \\
\hline Task Variety & 0.723 & -0.032 \\
\hline Task Identity & 0.088 & 0.211 \\
\hline Task Significance & $0.035^{\star *}$ & 0.230 \\
\hline Task Feedback & $0.035^{\star *}$ & 0.286 \\
\hline Task Interdependence & $0.005^{\star *}$ & 0.319 \\
\hline $\begin{array}{l}\text { Dependent Variable: Team Effectiveness } \\
\left.{ }^{*}\right)=\text { Significance }<0.05\end{array}$ & &
\end{tabular}

This study also discovered that the mean of team maintenance was categorized low at 3.14. As the Regulation of Indonesian Ministry of Health No. 67 of 2016 about TB prevention on the workload of team depends on the working area of primary healthcare centers. Primary healthcare centers that have less than four members but work in a broader scope will face more difficulties when they are given more workload to achieve their target. Performance, patients with TB, team workload may affect the low perception of team maintenance

An organization had their strategy to organize team and their work to be welldistributed according to the organization's needs (Mintzberg, 2007). The organization applies a structure as a technique to differentiate and integrate its task framework with the authority (Lawrence and Lorsch, 1967). The results of this study found an organization could design its structure when members' tasks had been decided to support cultural values

The Effect of... and norms which shape the team's behaviors and goals (Musibau, Oluyinka and Long, 2011).

Table 3 illustrates the results of multivariable dimension test between organization's structure and task characteristics in the implementation of TB prevention program in all primary healthcare centers of Surabaya. This study found a significant effect of the span of control on task characteristics with a Pvalue of 0.000 , which was less than $\alpha$ (0.05). The beta value of span of control was 0.538 , meaning perceiving the span of control as effective gives $53.8 \%$ possibilities to have high task characteristics. Primary healthcare centers of Surabaya apply a hierarchical structure defined by McShane and Glinow (2018) as a flat and team-based structure. Such hierarchical team-based structure has a wide span of control because the primary healthcare centers supervise the team infrequently. The team appointed one or more people as a span of control to report to the managers of the primary healthcare 
centers and Surabaya District Health Office.

The number of people assigned as a span of control significantly affects perception of task characteristics as the span of control corresponds with perception of given workloads. Some studies found similar findings that a span of control significantly affected perception of members' roles (Wong et al., 2015). Each task determines members' roles in a team. Some empirical studies further discovered that for giving a full-time job to a span of control in TB prevention program was an old system due to incompatibility of tasks (Omery et al., 2019). Health workers usually have a narrow span of control, in which only one person is appointed to report others' tasks to the leader. Using this span of control system, members will have good perception of task characteristics and focus on particular tasks.

Moreover, Table 3 presents the centralization dimension affected task characteristics significantly with the $\mathrm{P}$ value of 0.017 , it was less than $\alpha$ value (0.05). Centralization is the way an organization make their decision (McShane and Glinow, 2018). On behalf of an organization, a team also needs the authority to decide unpredictable agenda and predetermined ones. For the implementation of TB prevention program, centralization is vital to support team work. The centralisation dimension had a beta value of 0.315 , meaning that effective centralization could result in $31.5 \%$ of good perception of task characteristics.

Moreover, an organization could apply centralization to solve coordination issues (Veetil, 2017). It showed a positive effect of centralization on task characteristics. However, Borman, Ilgen and Klimoski (2003) mentioned that centralization had a negative effect on perception of task characteristics. However, the results of this study explained due to the hierarchical structure and system, the centralization system made the teams follow the leader's decision. According to McShane and Glinow (2018), many organizations adopt the centralization system in which leaders hold power to make decision and vision. As a result, members could perceive the leaders' decision to pursue common vision and mission which help them to understand task characteristics.

Table 3 also shows formalization dimension had no significant effect on task characteristics with the P-value of 0.128 which made its beta value was meaningless. Contrarily, the formalization dimension had implicit effects on work performance (Mutafa et al., 2019). The Regulation of Indonesian Ministry of Health No. 67 of 2016 about TB prevention states formalization for health workers to TB prevention program can operate as long as the policy does not change. Standard Operating Procedures (SOPs) on task descriptions had been applied by those who had a low or good perception of task characteristics. Even though perception of task characteristics is low, doctors, nurses, and healthy analysis will still check and give treatments to patients or TB suspects. As a result, it seems that formalization dimension did not affect perception of task characteristics.

Table 4 demonstrates task characteristics affected task significance, task feedback, and task interdependence significantly. This result was relevant with some other studies which state that team effectiveness was correlated with task characteristics (Pai et al., 2018). Task characteristics reflect employees' behavior, attitude, and feeling about their job (Fraccaroli, Zaniboni and Truxillo, 2017). Task characteristics stimulate strategies used by each member (Janssen and Brumby, 2015).

In the primary healthcare centers, the teams had similar task characteristics. 
Different task characteristics among team members are crucial for team performance. Due to the high annual target of TB detection and success rate, task characteristics will affect team performance.

Furthermore, this study found task significance dimension affected task effectiveness with the P-value of 0.035 which was less than $\alpha$ value (0.05). This dimension had the beta value of 0.230 , indicating that good perception of task significance contributed $23.0 \%$ to good perception of team effectiveness. Even though task significance did not directly affect performance, it still affected task engagement and performance significantly (Grobelna, 2019). Task significance is a team responsibility, which exerts meaningful experience (McShane and Glinow, 2018). However, some other studies showed task significance dimension had a significant relationship with task performance (Zawawi, Nasurdin and Mohd, 2017). These studies clarified that task significance became a stimulus and gave direct or indirect effects on team effectiveness.

The teams in TB prevention program worked closely with TB patients, and thus their task significance was relatively high. For instance, a doctor is responsible for a medical check, diagnosis, and drug prescription for each patient or tuberculosis suspect. Nurses take care of and ensure TB patients complete treatments. Health analysists, for example, check patient's sputum in supporting doctor's diagnosis.

The next dimension is task feedback, which also affected team effectiveness significantly with the P-value of 0.035 which was less than $\alpha$ value (0.05). The beta value was 0.286 indicating good perception of task feedback possibly contributed to $28.6 \%$ of good team effectiveness. Johari and Yahya (2016) found similar findings which task feedback had a significant effect on task performance. Veleme (2015) mentioned that positive or negative feedback was important to make the team effective. Moreover, positive feedbacks had a strong relationship with ask performance (Evans, 2019). Employees who had good task feedback had a greater chance to perform effectively as they were motivated to achieve targets (GagnonDolbec, McKelvie, and Eastwood, 2017). Task feedback could evaluate team performance so that employees could improve themselves later on.

Despite its impact on task performance, Brown et al. (2019) discovered that team feedback would be effective if it was regularly done. Conversely, individuals and teams without regular feedback could face failures. Moreover, team feedback is supported by organization's culture (Evans, 2019).

Task feedback needs both coordination and communication among the teams in the implementation ofTB prevention program. Task feedback given to more number of employees will be less effective and irregular.

Regarding task interdependence, this study found the P-value of 0.005 was smaller than $\alpha$ value (0.05). It indicates this dimension affected team effectiveness significantly. The beta value of 0.319 showed a meaningful result in which good task interdependence could contribute to $31.9 \%$ good perception of team effectiveness. Task interdependence can improve psychological state of each member (Tuuli, 2018). As a result, employees could performance tasks effectively. A team with good perception of task interdependence would encourage teamwork in achieving targets (Cooke, Hilton, and Sciences, 2015). Supporting this fact, Lee et al. (2015) also found that task interdependence had a positive effect on performance. Task interdependence in the implementation of TB prevention 
program interconnects doctors, nurses, and health analysts who have noninterchangeable roles.

Overall, this study only focused on organization's structure and task characteristics in the primary healthcare centers, but it did not include other factors, i.e., individual factors which perhaps affect team effectiveness.

\section{CONCLUSION}

Organization's structure (span of control and centralization) had a significant effect on task characteristics. In the same way, task characteristics (task significance, task feedback, and task interdependence) affected team effectiveness significantly. Good perception of task characteristics exists when leaders and members build good communication. This study also concluded task characteristics became an intervening variable of organization's structure and team effectiveness. To recommend, a psychological training on communication could be a way of improving relationship among the team members.

\section{CONFLICT OF INTEREST}

Authors declared that there was no conflict of interest in this study.

\section{REFERENCES}

Borman, W. C., Ilgen, D. R. and Klimoski, R. J. (2003) Handbook of Psychology Volume 12 Industrial and Organizational Psychology. 12th Editi. Edited by B. Weiner, Irving. New Jersey: John Wiley \& Sons, Inc.

Brown, B. et al. (2019) 'Clinical Performance Feedback Intervention Theory (CP-FIT): a new theory for designing, implementing, and evaluating feedback in health care based on a systematic review and meta-synthesis of qualitative research', Implementation Science. Implementation Science, 14(40), pp. 1-25.

East Java Provincial Health Office (2017) East Java Health Profile 2017. Surabaya.

Ehrhardt, K. et al. (2018) 'Examining Project Commitment in CrossFunctional Teams: Antecedents and Relationship with Team Performance', Journal of Business and Psychology, 29(3), pp. 443-461. doi: $10.1007 / \mathrm{s}$.

Evans, T. and Dobrosielska, A. (2019) 'Feedback-seeking culture moderates the relationship between positive feedback and task performance', Current Psychology. Current Psychology.

Folami, L. B. and Jacobs, F. (2005) 'The Joint Effect Of Task Characteristics And Organizational Context On Job Performance: A Test Using SEM', Journal of Business \& Economics Research, 3(7), pp. 25-40.

Fraccaroli, F., Zaniboni, S. and Truxillo, D. (2017) 'Job Design and Older Workers', in Age Diversity in the Workplace. Bingley: Emerald Publishing Limited, pp. 139-159. doi: https://doi.org/10.1108/S1877636120170000017008.

Gagnon-Dolbec, A., McKelvie, S. J. and Eastwood, J. (2017) 'Feedback, Sport-Confidence and Performance of Lacrosse Skills', Current Psychology, 38, pp. 1622-1633. doi: https://doi.org/10.1007/s12144-0179720-7.

Grobelna, A. (2019) 'Effects of individual and job characteristics on hotel contact employees' work engagement and their performance outcomes', International Journal of Contemporary Hospitality Management, 31(1), pp. 349-369. doi: https://doi.org/10.1108/IJCHM- 
08-2017-0501.

Hage, J. and Aiken, M. (1967) 'Relationship of Centralization to Other Structural Properties', Administrative Science Quarterly, 12(1), pp. 72-92.

Indonesian Ministry of Health (2017) Integrated Tuberculosis Information System 10.04. Jakarta.

Janssen, C. P. and Brumby, D. P. (2015) 'Strategic Adaptation to Task Characteristics, Incentives, and Individual Differences in DualTasking', PLoS ONE, 10(7), pp. 132.

doi: https://doi.org/10.1371/journal.pone. 0130009.

Johari, J. and Yahya, K. K. (2016) 'Job Characteristics, Work Involement, And Job Performance of Public Servants', European Journal of Training and Development, 40(7), pp. 554-575. doi: http://dx.doi.org/10.1108/EJTD-072015-0051.

Jones, G. R. (2013) Organizational Theory, Design, and Change. 7th Editio. Texas: A\&M University.

Kramer, W. S., Thayer, A. L. and Salas, E. (2013) 'Goal setting in teams', in Locke, E. A. and Latham, G. P. (eds) New Developments in Goal Setting and Task Performance. England: Routledge, pp. 287-310. doi: 10.4324/9780203082744.

Lawrence, P. R. and Lorsch, J. W. (1967) 'Differentiation and Integration in Complex Organizations', Administrative Science Quarterly, 12(1), pp. 1-47.

Lee, C. et al. (2015) 'The effects of task interdependence, team cooperation, and team conflict on job performance', Social Behavior and Personality: an international journal, 43(4), pp. 529-536.

Lukas, C. V., Mohr, D. C. and Meterko, M. (2009) 'Team effectiveness and organizational context in the implementation of a clinical innovation', Quality Management in Health Care, 18(1), pp. 25-39. doi: 10.1097/01.QMH.0000344591.5613 3.90 .

McShane, S. and Glinow, M. Von (2018) Organizational behavior: emerging knowledge, global reality. 8th Editio. New York: McGraw-Hill Education.

Mintzberg, H. (2007) Tracking strategies: Toward a general theory of strategy formation. New York: Oxford University Press.

Musibau, A. A., Oluyinka, S. and Long, C. S. (2011) 'The Relationship Between Strategic Planning and the Effectiveness of Marketing Operations', International Journal of Innovation Management and Technology, 2(5), pp. 390-396.

Mustafa, G. et al. (2019) 'Structural Impacts on Formation of SelfEfficacy and Its Performance Effects', Sustainability, 11(3), pp. 124. doi: doi:10.3390/su11030860.

National Research Council (2015) Enhancing the Effectiveness of Team Science. Washington DC: The National Academies Press. doi: 10.17226/19007.

Omery, A. et al. (2019) 'Reexamining Nurse Manager Span of Control With a 21st-Century Lens', Nursing Administration Quarterly, 43(3), pp. 230-245. doi: http://dx.doi.org/10.1097/NAQ.00000 00000000351.

Pai, H.-C. et al. (2018) 'Modeling the antecedents of clinical examination performance: Task characteristics and psychological state in nursing students.', Nurse Education Today, 69, pp. 142-148. doi: http://dx.doi.org/10.1016/j.nedt.2018. 07.016 .

Rhys, A. et al. (2009) 'Centralization, Organizational Strategy, and Public 
Service Performance', Journal of Public Administration Research and Theory, 19(1), pp. 57-80.

Tuuli, M. M. (2018) 'What has project characteristics got to do with the empowerment of individuals, teams and organisations?', International Journal of Managing Projects in Business, 11(3), pp. 708-733. doi: https://doi.org/10.1108/IJMPB-082017-0097.

Veetil, V. P. (2017) 'Coordination in Centralized and Decentralized Systems', International Journal of Microsimulation, 10(2), pp. 86-102.
Wong, C. A. et al. (2015) 'Examining the Relationships between Span of Control and Manager Job and Unit Performance Outcomes', Journal of Nursing Management, 23(2), pp. 156-168. doi: 10.1111/jonm.12107.

World Health Organization (2017) Global Tuberculosis Report. Geneva.

Zawawi, A., Nasurdin, A. and Mohd, A. (2017) 'The impact of task characteristics on the performance of nursing teams', International Journal of Nursing Sciences. Elsevier Taiwan LLC, 4(3), pp. 285290. doi: 10.1016/j.jnss.2017.03.009 